\title{
Chemokine Gene Expression and Clonal Analysis of B Cells in Tissues Involved by Lymphoid Interstitial Pneumonitis from HIV-Infected Pediatric Patients
}

\author{
Julie Teruya-Feldstein, M.D., Douglas W. Kingma, M.D., Andrew Weiss, M.D., \\ Lynn Sorbara, Ph.D., Parris R. Burd, Ph.D., Mark Raffeld, M.D., Brigitta U. Mueller, M.D., \\ Giovanna Tosato, M.D., Elaine S. Jaffe, M.D.
}

Laboratory of Pathology (JTF, DWK, AW, LS, MR, ESJ), Hematopathology Section, National Cancer Institute, National Institutes of Health, Bethesda, Maryland; Center for Biologics Evaluation and Research (PRB, GT), Food and Drug Administration, Bethesda, Maryland; and Texas Children's Cancer Center (BUM), Houston, Texas

\begin{abstract}
Lymphoid interstitial pneumonitis (LIP), a frequent pulmonary complication in HIV-infected pediatric patients, is characterized histologically by marked infiltration of lymphoid cells. We sought to evaluate the nature and pathogenesis of the lymphoid infiltrates and to examine the relationship of LIP to pulmonary MALT lymphoma that has been described in pediatric HIV positive patients. To examine the potential contribution of chemokines and cytokines to the inflammatory cell recruitment in tissues involved by lymphoid interstitial pneumonitis from HIV-infected pediatric patients, RNA was extracted from paraffin-embedded tissues from five lung biopsies in four pediatric HIV-positive patients and from five control, normal lung biopsies in five HIV-negative patients and was analyzed by semiquantitative RT-PCR for the expression of cytokines (TNF- $\alpha$, GM-CSF, IFN- $\gamma$, IL-4, IL-6, IL-10, and IL-18) and chemokines (IP-10, Mig, regulated upon activation, normal $\mathrm{T}$ expressed and secreted [RANTES], and MIP1- $\alpha$ and $\beta$ ) after normalization for G3PDH. Expression of IL-18 was increased, as well as expression of IFN- $\gamma$-inducible chemokines IP-10 and Mig in LIP tissues compared with controls. RANTES and MIP1- $\alpha$ and - $\beta$ were also increased in pediatric LIP lesions compared with controls. In contrast, expression of TNF- $\alpha$, GM-CSF, IL-10, and IL-6 was variable in LIP tissues and controls. In addition, clonality of
\end{abstract}

Copyright (C) 2001 by The United States and Canadian Academy of Pathology, Inc.

VOL. 14, NO. 10, P. 929, 2001 Printed in the U.S.A.

Date of acceptance: May 25, 2001.

This work was in part presented at the National AIDS Malignancy Conference, April 28-30, 1997, in Bethesda, MD.

Julie Teruya-Feldstein, M.D., is now affiliated with Memorial SloanKettering Cancer Center, Department of Pathology, New York, New York. Address reprint requests to: Elaine S. Jaffe, M.D., Hematopathology Section, Laboratory of Pathology, National Cancer Institute, National Institutes of Health, Building 10, Room 2N202, 10 Center Drive MSC 1500 , Bethesda, MD 20892-1500; fax: 301-402-2415. the B-cell population was evaluated by VDJ-PCR. A polyclonal B-cell population was shown in all five biopsies from five patients with LIP; and in one patient with concurrent LIP and MALT lymphoma, a band of increased intensity was observed in the LIP biopsy that was identical in size to the monoclonal band in the concurrent MALT lymphoma biopsy. These results provide evidence of high-level expression of certain chemokines in lymphoid interstitial pneumonitis tissues and suggest that chemokines and cytokines may play an important role in the recruitment of inflammatory cell infiltrates into these tissues. In addition, LIP may represent an early stage of MALT lymphoma or an immunologic response to a chronic antigenic stimulus that may provide a milieu or microenvironment for the evolution of a monoclonal B-cell population.

KEY WORDS: Chemokine, HIV, LIP, Lymphoma, Pediatric.

Mod Pathol 2001;14(10):929-936

Pulmonary lymphoid infiltrates range from pulmonary lymphoid hyperplasia (PLH), lymphoid interstitial pneumonitis (LIP), polyclonal polymorphic B-cell lymphoproliferative disorder, and malignant lymphoma (1). LIP is a common pulmonary complication in pediatric AIDS patients, present in $\leq 75 \%$ of cases $(2,3)$. Recently, a spectrum of mucosa-associated lymphoid tissue (MALT) lesions (4), multilocular thymic cysts associated with LIP (5-8) and a spectrum of pulmonary lymphoid infiltrates have been described in pediatric HIVinfected patients (1).

Malignant lymphoma of mucosa-associated lymphoid tissue (MALT) is a low-grade B-cell lymphoma with a predilection for mucosa-associated sites such as the stomach, lung, salivary gland, lac- 
rimal glands, thyroid, skin, and thymus. These tumors are localized and have a low risk of dissemination to bone marrow and lymph nodes (9-12). MALT lymphoma is preceded by inflammatory reactive lymphoid tissues such as those seen in Sjogren's syndrome, Hashimoto's thyroiditis, and Helicobacter pylori gastritis (13).

We previously reported two cases of pulmonary marginal zone B-cell lymphoma of mucosaassociated lymphoid tissue (ML-MALT) associated with LIP (14-15). Histologically, LIP shows a diffuse peribronchial and interstitial lymphoid infiltrate in the pulmonary parenchyma with polyclonal plasma cells. The etiology and pathogenesis is not known. It has been postulated that bronchus-associated lymphoid tissue and LIP may represent a premalignant organ response to an antigenic stimulus (16) that may progress to MALT lymphoma. In addition, immune dysregulation is thought to be involved in the pathogenesis of LIP, which can be seen also in adults with autoimmune disease $(2,8,17,18)$.

Recently, increased cytokine gene expression, including interferon- $\gamma$ (IFN- $\gamma$ ), interleukin-10 (IL-10), transforming growth factor- $\beta$ (TGF- $\beta$ ), and interleukin-1 (IL-1) was described in a murine model of AIDS (MAIDS)-associated interstitial pneumonitis $(19,20)$. The model for development of MAIDS-associated interstitial pneumonitis proposed that infection with LP-BM5 retrovirus leads to an inappropriate cellular interaction between $\mathrm{T}$ and B cells, which polyclonally activate a large fraction of $\mathrm{T}$ cells in the infected animal. Inappropriate interactions between Th1 $\mathrm{T}$ cells and antigenpresenting $\mathrm{B}$ cells induce chronic interferongamma production that causes chronic macrophage activation and ultimate sustained inflammation and tissue remodeling of the lung $(19,20)$. We wished to determine whether cytokine and chemokine gene expression play a role in the recruitment of inflammatory cell infiltrates into LIP tissues and whether the presence of activated lymphoid cells may contribute to the evolution of a clonal B-cell population, indicating a clonal relationship between pulmonary LIP and MALT lymphoma in pediatric HIV-infected patients.

\section{MATERIALS AND METHODS}

\section{Case Selection}

Patient cases were retrieved from the files of the Laboratory of Pathology, Center for Cancer Research, National Cancer Institute, National Institutes of Health. Criteria for study inclusion included the following: 1) the patient being HIV positive and $<18$ years of age; 2 ) the patient having a diagnosis of pulmonary LIP and/or malignant lymphoma of MALT; and 3) the availability of paraffin or frozen-tissue blocks for immunohistochemical studies, immunoglobulin heavy-chain gene rearrangement analysis by polymerase chain reaction (PCR), and chemokine/cytokine gene expression by reverse-transcription-mediated polymerase chain reaction (RT-PCR). The study population was comprised of six patients total, including 3 females and 3 males, ranging in age from 2-15 years of age at the time of the diagnostic biopsy. Of the six patients, four were diagnosed with LIP, one with pulmonary MALT lymphoma, and one with concurrent LIP and MALT lymphoma. Five patients had vertically acquired HIV, and one patient was infected after blood transfusion (Table 1).

\section{Immunohistochemistry}

Staining was performed after antigen retrieval using 50 mM TRIS buffer, $\mathrm{pH}$ 7.4, and microwaving for 10 minutes at $700 \mathrm{~W}$. Staining was performed without enzyme digestion on an automated immunostainer (Ventana Medical Systems, Inc., Tucson, AZ). A panel of monoclonal antibodies was used: CD20 (L26) and CD3 (DAKO, Carpinteria, CA); CD43 (Leu 22, Beckton Dickinson, San Jose, CA); and antikappa and anti-lambda (Biosource, Burlingame, CA; Table 2).

\section{Epstein-Barr Virus In Situ Hybridization}

In situ hybridization used an Epstein-Barr virus (EBV) probe specific for EBV-encoded small RNAs (EBER), as described previously (21), using an automated system (Ventana).

TABLE 1. Pediatric HIV Patients with LIP and HIV Transmission Status

\begin{tabular}{|c|c|c|c|c|c|}
\hline Case No. & Age (y) & Sex & Biopsy Site & Diagnosis & $\begin{array}{l}\text { Mode of HIV } \\
\text { Infection }\end{array}$ \\
\hline 1 & 7.3 & $\mathrm{~F}$ & Lung & LIP & Vertical \\
\hline 2 & 7.1 & $\mathrm{~F}$ & $\begin{array}{l}\text { Lung } \\
\text { Lung }\end{array}$ & $\begin{array}{l}\text { ML-MALT } \\
\text { LIP }\end{array}$ & Vertical \\
\hline 3 & 12 & $\mathrm{~F}$ & Lung & LIP & Vertical \\
\hline 4 & 2 & M & Lung & LIP & Vertical \\
\hline 5 & 3 & M & Lung & LIP & Vertical \\
\hline 6 & 15 & M & Lung & ML-MALT & Transfusion \\
\hline
\end{tabular}

F, female; M, male; LIP, lymphocytic interstitial pneumonitis; ML-MALT, malignant lymphoma of mucosa-associated lymphoid tissue. 
TABLE 2. Immunohistochemistry and Molecular Analysis of Tissues with LIP in Pediatric HIV Patients

\begin{tabular}{|c|c|c|c|c|c|c|c|}
\hline Case & Diagnosis & L26 & Leu22 & CD3 & Kappa & Lambda & IgH Chain GR ${ }^{\mathrm{a}}$ \\
\hline 1 & LIP & ++ & No & ++ & Polytypic & Polytypic & Polyclonal (PCR) \\
\hline \multirow[t]{2}{*}{2} & ML-MALT & +++ & Yes & + & - & Monotypic & Monoclonal $(\mathrm{PCR}+\mathrm{SBH})^{\mathrm{b}}$ \\
\hline & LIP & & No & & Polytypic & Polytypic & Polyclonal (PCR) \\
\hline 3 & LIP & $+1++$ & No & $++I+++$ & Polytypic & Polytypic & Polyclonal (PCR) \\
\hline 4 & LIP & ++ & No & ++ & Polytypic & Polytypic & Polyclonal (PCR) \\
\hline 5 & LIP & ++ & No & ++ & Polytypic & Polytypic & Polyclonal (PCR) \\
\hline 6 & ML-MALT & +++ & Yes & + & - & Monotypic & Monoclonal (PCR) \\
\hline
\end{tabular}

${ }^{\mathrm{a}}$ Immunoglobulin heavy chain gene rearrangement.

b Southern blot hybridization.

LIP, lymphocytic interstitial pneumonitis; ML-MALT, malignant lymphoma of mucosa-associated lymphoid tissue;,,++++++ , relative numbers $\mathrm{B}$ cells/plasma cells (L26, kappa, lambda) and T cells (CD3).

Polymerase Chain Reaction for Immunoglobulin Heavy-Chain Gene Rearrangement and Human Herpes Virus-8

DNA was extracted from paraffin-embedded tissue sections, PCR was performed with primers to Framework III of the variable and joining segments (21), and products were analyzed by polyacrylamide gel electrophoresis (PAGE). PCR was also performed to detect $\mathrm{HHV}-8$ viral sequences using primers (HHV-8 1-5:5'-TAGCCCAAAGGATTCCACCAT-3' and HHV-8 1-3:5'-GGATCCGTGTTGTCTACGTC-3') and conditions as previously published (22), and products were analyzed on agarose gels. The MALT lymphoma from Case 2 was also studied by Southern blot hybridization (14).

\section{Reverse Transcriptase-Mediated PCR}

RNA extraction from paraffin-embedded tissue was performed as previously described with modifications (23). Briefly, six to ten $20-\mu \mathrm{m}$ paraffin sections were deparaffinized three times in $x y-$ lene (with heating at $55^{\circ} \mathrm{C}$ for $10 \mathrm{~min}$ ), twice in $100 \%$ ethanol and twice in $70 \%$ ethanol. Sections were resuspended in $1 \mathrm{~mL}$ extraction buffer (10 mм NaCl, 50 mм Tris-HCL, pH 7.4, 20 mм EDTA, $1 \%$ SDS) at $55^{\circ} \mathrm{C}$ overnight with $500 \mu \mathrm{g} / \mathrm{uL}$ of proteinase K. After addition of $1 \mathrm{~mL}$ of RNA Trizol (Gibco/BRL, Life Technologies, Gaithersburg, $\mathrm{MD}$ ) and $200 \mu \mathrm{L}$ of chloroform, followed by centrifugation, the aqueous phase was combined with an equal volume of isopropanol. The precipitated pellet was washed with $70 \%$ ethanol and resuspended in diethylpyrocarbonate-treated water.

RT-PCR was performed as previously described with modifications for highly degraded RNA obtained from paraffin-embedded tissues (23). For semiquantitative results, PCR products were detected by quantitating incorporated ${ }^{32} \mathrm{P}(\alpha$-dCTP) radioactivity. The amount of each RNA sample used was selected on the basis of equivalent amounts of glyceraldehyde-3phosphate dehydrogenase (G3PDH) cDNA amplified from each sample. Variability of results from different experiments was minimized by use of a standard con- trol RNA preparation from cultured IFN- $\gamma$ stimulated endothelial cells. RNA samples were DNAse treated (GIBCO/BRL, Life Technologies, Gaithersburg, MD), then subjected to an initial assay for amplifiable contaminating genomic DNA using primers specific for G3PDH mRNA. Positive samples were retreated with DNase; negative samples $(2-5 \mu \mathrm{g})$ were reverse transcribed using an RNase H-RT (Superscript; GIBCO/ BRL). The resultant cDNA (25-100 ng) was amplified as previously described with modifications (23). Primers, listed in Table 3, were designed for amplification of short amplicons ( $80-130 \mathrm{bp}$ ) from highly degraded RNA, and spanned at least one splice junction. Genomic DNA could be distinguished from mRNA or cDNA. Appropriately sized amplicon products using cell line controls were confirmed using molecular weight markers. Optimum primer-annealing temperatures were chosen using a temperature gradient, and amplifications were performed in a thermocycler (Stratagene Robocycler 96 with the Hot Top Assembly, La Jolla, CA), adding 1.25U Platinum Taq polymerase (Gibco/BRL) after heating at $94^{\circ} \mathrm{C}$ for 3 minutes ("Hot Start"), followed by 35 amplification cycles $\left(94^{\circ} \mathrm{C}, 45 \mathrm{~s}\right.$; primer annealing temperature as specified in Table 3, and extension at $72^{\circ} \mathrm{C}$ ). These were then maintained at $4^{\circ} \mathrm{C}$ until analysis. The entire amplification reaction ( $50 \mu \mathrm{L}$ ) was analyzed by electrophoresis on $8 \%$ acrylamide (Long Ranger; AT Biochem, Malvern, PA) Tris-borate EDTA gels (PAGE), followed by autoradiography and quantitation by phosphorimage analysis using ImageQuant Version 3.3 software (Molecular Dynamics). Band integrations were obtained as the sum of values for all pixels above background (areas around each sample). Integrated volumes were then normalized to the standard positive control (IFN- $\gamma$-stimulated endothelial cells). Standard-normalized integrated values for each sample were then normalized for the results of RT-PCR amplification for G3PDH. The results of RT-PCR analysis are presented as the geometric means of the absolute numbers of normalized arbitrary units (pixels)/sample for each chemokine and cytokine. 


\begin{tabular}{|c|c|c|c|c|}
\hline PCR Product & $\begin{array}{c}\text { Genbank } \\
\text { Accession No. }\end{array}$ & Primer Sequence $\left(5^{\prime} ; 3^{\prime}\right)$ & $\begin{array}{l}\text { Product } \\
\text { Size }\end{array}$ & $\begin{array}{l}\text { Annealing } \\
\text { Temperature }\end{array}$ \\
\hline Mig & $\begin{array}{l}X 72755 \\
\text { S60728 }\end{array}$ & $\begin{array}{l}\text { TTCCTCTTGGGCATCATCTTGCTG; } \\
\text { GGTCTTTCAAGGATTGTAGGTGGA }\end{array}$ & 123 & 57 \\
\hline IP-10 & $\begin{array}{l}\text { X02530 } \\
\text { M17752 }\end{array}$ & $\begin{array}{l}\text { GGAACCTCCAGTCTCAGCACC; } \\
\text { GCGTACGGTTCTAGAGAGAGGTAC }\end{array}$ & 108 & 57 \\
\hline IFN- $\gamma$ & $\begin{array}{l}\text { V00536 } \\
\text { AO4665 }\end{array}$ & $\begin{array}{l}\text { GGACCCATATGTAAAAGAAGCAGA; } \\
\text { TGTCACTCTCCTCTTTCCAATTCT }\end{array}$ & 121 & 57 \\
\hline MIP- $1 \alpha$ & M25315 & $\begin{array}{l}\text { CTCTGCACCATGGCTCTCTGCAAC; } \\
\text { TGTGGAATCTGCCGGGAGGTGTAG }\end{array}$ & 87 & 62 \\
\hline MIP- $1 \beta$ & M25316 & $\begin{array}{l}\text { CTCCTCATGCTAGTAGCTGCCTTC; } \\
\text { GGTGTAAGAAAAGCAGCAGGCGGT }\end{array}$ & 90 & 62 \\
\hline RANTES & M21121 & $\begin{array}{l}\text { GGCACGCCTCGCTGTCATCCTCA; } \\
\text { CTTGATGTGGGCACGGGGCAGTG }\end{array}$ & 130 & 65 \\
\hline TNF- $\alpha$ & M10988 & $\begin{array}{l}\text { AGAGGGAAGAGTCCCCCAGGA; } \\
\text { TCAGCTTGAGGGTTTGCTACAA }\end{array}$ & 81 & 59 \\
\hline GM-CSF & M10663 & $\begin{array}{l}\text { CCTGCTGCTCTTGGGCACTGTGGC; } \\
\text { TCAGGTTCAGGAGACGCCGGGCCT }\end{array}$ & 121 & 59 \\
\hline IL-4 & M13982 & $\begin{array}{l}\text { AGCCTCACAGAGCAGAAGACTCTG; } \\
\text { CAGCCCTGCAGAAGGTTTCCTCTC }\end{array}$ & 99 & 61 \\
\hline IL-10 & U16720 & $\begin{array}{l}\text { CTTCGAGATCTCCGAGATGCCTTC; } \\
\text { GGATCATCTCAGACAAGGCTTGGC }\end{array}$ & 121 & 53 \\
\hline IL-18 & D49949 & $\begin{array}{l}\text { ATGGCTGCTGAACCAGTAGAAGAC; } \\
\text { GCCAAAGATATCTGATTCGAAG }\end{array}$ & 116 & 61 \\
\hline IL-6 & Y00081 & $\begin{array}{l}\text { AGGAGCCCAGCTATGAACTCCTTC; } \\
\text { TGGAATCTTCTCCTGGGGGTACTG }\end{array}$ & 114 & 61 \\
\hline G3PDH & $\begin{array}{l}\text { M33197 } \\
\text { M32599 }\end{array}$ & $\begin{array}{l}\text { GCCACATCGCTAAGACACCATGGG; } \\
\text { CCTGGTGACCAGGCGCCCAAT }\end{array}$ & 78 & 59 \\
\hline
\end{tabular}

Mig, monokine induced by interferon- $\gamma$; IP-10, interferon- $\gamma$ inducing protein-10; IFN- $\gamma$, interferon-gamma; MIP-1 $\alpha$ and - $\beta$, macrophage inflammatory protein 1-alpha and beta; RANTES, regulated upon activation, normal T expressed and secreted; TNF- $\alpha$, tumor necrosis factor-alpha; GM-CSF, granulocyte-macrophage stimulating factor; IL-4, interleukin-4; IL-10, interleukin-10; IL-18, interleukin-18; IL-6, interleukin-6; G3PDH, glyceraldehyde3-phosphate dehydrogenase.

\section{RESULTS}

Tissues involved by LIP and ML-MALT from HIVpositive pediatric patients were analyzed by immunohistochemistry, in situ hybridization for EpsteinBarr virus, PCR for HHV-8, and immunoglobulin heavy-chain gene rearrangement (VDJ-PCR), and RT-PCR for chemokine/cytokine gene expression to evaluate the nature and pathogenesis of the pulmonary lymphoid infiltrates and to examine the clonal relationship of LIP to pulmonary MALT lymphoma in pediatric HIV-positive patients.

Histologically, the pulmonary parenchyma involved by LIP showed a dense lymphoid infiltrate composed of germinal centers with scattered plasma cells and epithelioid histiocytes. Immunohistochemistry studies performed on the LIP biopsies showed an admixture of B (L26, CD20) and T (CD3) lymphocytes with polyclonal cells of B-cell lineage (Table 2, Fig. 1). The two patients with MALT lymphoma also histologically showed a dense lymphoid infiltrate extensively involving the pulmonary parenchyma. The neoplastic cells surrounded reactive follicles in a marginal zone or parafollicular pattern. The neoplastic cells were small but heterogeneous in morphology composed of small lymphocytic, plasmacytoid, monocytoid, and "centrocyte-like" features. The tumor cells expressed L26 (CD20) and co-expressed Leu 22 (CD43). The plasma cells showed monoclonal lambda light-chain restriction in the two cases of pulmonary MALT lymphoma.

PCR for HHV-8 was negative in five of five biopsies. In situ hybridization for Epstein-Barr virus was performed on two biopsies diagnosed as pulmonary MALT lymphoma and showed rare scattered cells, but overall was interpreted as negative.

Immunoglobulin heavy-chain gene rearrangement (VDJ-PCR) showed a polyclonal ladder in all 5 patients with LIP. In contrast, two patients with pulmonary MALT showed a dominant monoclonal band with a background polyclonal ladder pattern. One of the two cases of pulmonary MALT lymphoma showed immunoglobulin gene rearrangements of both heavy and light chains by Southern blot analysis (14), and the associated LIP biopsy from this patient showed a band of increased intensity, similar in size to that in the concurrent MALT lymphoma biopsy with a background polyclonal ladder pattern (Table 2, Fig. 2).

RNA was extracted from paraffin-embedded tissues from five lung biopsies in four pediatric HIVpositive patients and from five control, normal lung biopsies in five HIV-negative patients and was analyzed by semiquantitative RT-PCR for the expression of cytokines (TNF- $\alpha$, GM-CSF, IFN- $\gamma$, IL-4, IL-6, IL-10, and IL-18) and chemokines (IP-10; Mig; regulated upon activation, normal $\mathrm{T}$ expressed and secreted [RANTES]; and MIP1- $\alpha$ and $\beta$ ) after nor- 

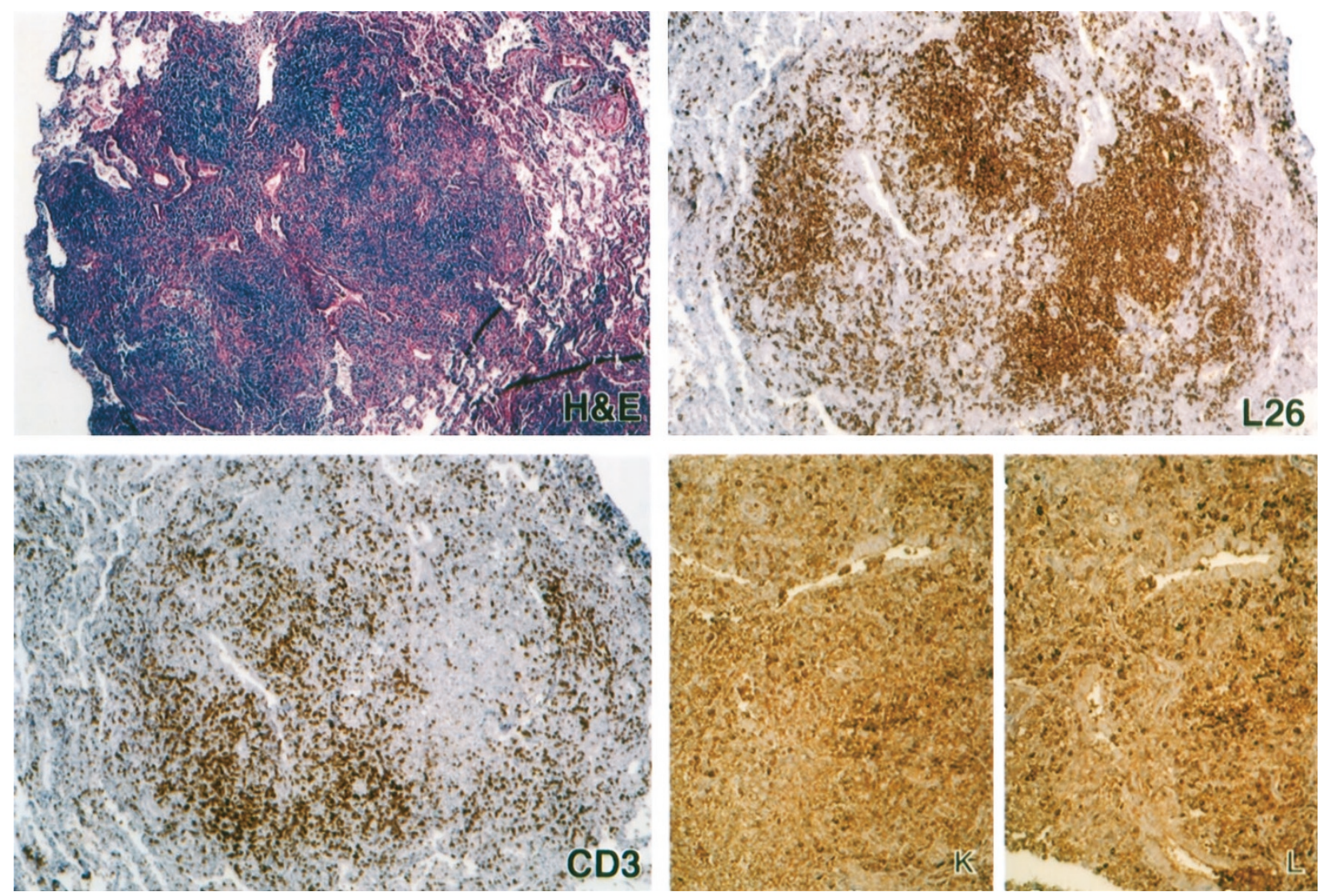

FIGURE 1. Immunohistochemical analysis of a representative case of lymphoid interstitial pneumonitis. Paraffin-embedded tissue sections were stained with hematoxylin and eosin; with a B-cell marker, L26 (CD20); with a T-cell marker, CD3; and with kappa and lambda (K and L, respectively). Primary antibodies were detected with biotinylated anti-mouse/rabbit IgG, followed by streptavidin-peroxidase complexes (magnification, $20 \times$ ). Note there is a mixture of B and T cells with many scattered polyclonal cells of B-cell lineage.

malization for G3PDH (Fig. 3). Consistent with the detection of IFN- $\gamma$ in a murine model of AIDSassociated LIP, IFN- $\gamma$ was also present in pediatric LIP tissues. Expression of a newly discovered molecule called IFN- $\gamma$-inducing factor or IGIF (now designated IL-18) was increased, as well as that of IFN- $\gamma$-inducible CXC chemokines IP-10 and Mig in LIP tissues, compared with controls. RANTES and MIP1- $\alpha$ and $-\beta$ were also increased in pediatric LIP lesions compared with controls. In contrast, expression of TNF- $\alpha$, GM-CSF, IL-10, and IL- 6 was variable in LIP tissues and controls, and IL-4 was not expressed in LIP tissues and controls (Fig. 4).

\section{DISCUSSION}

In this study, we provide evidence of high-level expression of certain chemokines and cytokines in LIP tissues from HIV-infected pediatric patients and suggest that chemokines and cytokines may play an important role in the recruitment of inflammatory cell infiltrates into these tissues. The microenvironment of the inflammatory cells in LIP may activate $B$ cells and contribute to the development of a monoclonal B-cell population. Analogous to Helicobacter pylori lymphocytic chronic gastritis and gastric MALT lymphoma, or myoepithelial sialadenitis and salivary gland MALT lymphoma $(24,25)$, LIP may therefore represent an early stage or a precursor lesion of pulmonary MALT lymphoma.

Recently, increased cytokine expression including IFN- $\gamma$, IL-10, TGF- $\beta$, and IL- 1 was described in a murine model of AIDS-associated interstitial pneumonitis $(19,20)$. We also observed IFN- $\gamma$ mRNA expression in LIP tissues from pediatric HIVinfected patients that was absent in control normal lung tissues from non-HIV infected patients. However, in addition, we showed increased production of IFN- $\gamma$-inducible molecules such as IP-10 and Mig that are chemoattractants for $\mathrm{T}$ and NK cells $(26,27)$ in LIP tissues compared with control normal lung tissues. A newly discovered molecule, called IGIF (now designated IL-18) with potent IFN$\gamma$-inducing activity (28), was also increased in LIP tissues compared with in normal lung controls, explaining the presence of IFN- $\gamma$, IP-10, and Mig. IL-18 is produced by activated T cells (28) and can inhibit IL-10 production (29). In addition, chemokines related to activated T-cell and macrophage expression such as RANTES and MIP1- $\alpha$ and $-\beta$ mRNA levels were increased in LIP tissues com- 


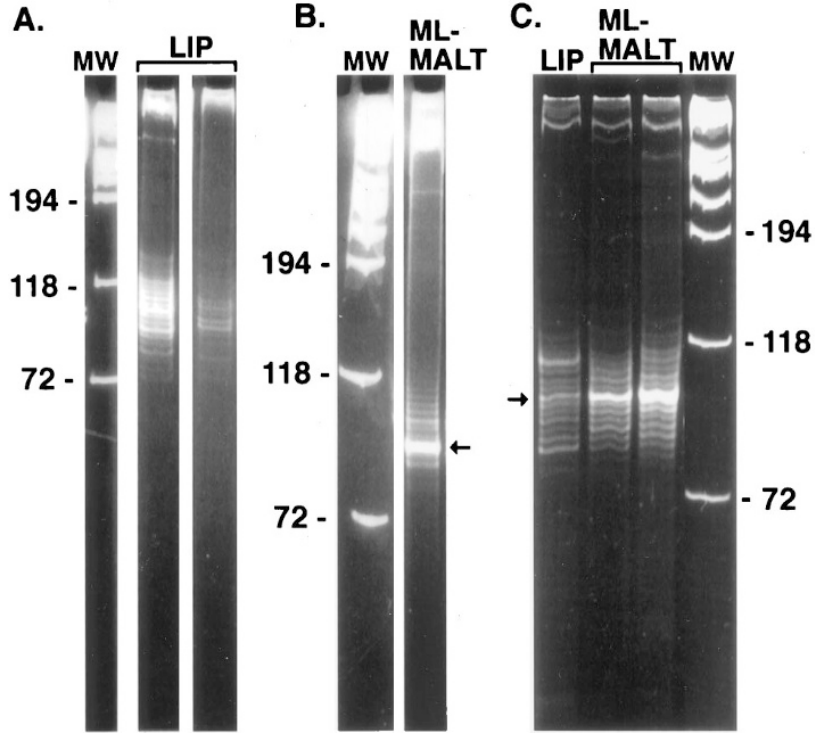

FIGURE 2. Immunoglobulin heavy-chain gene rearrangement polymerase chain reaction (VDJ-PCR) of representative cases of lymphoid interstitial pneumonitis (LIP) and pulmonary mucosaassociated lymphoid tissue (MALT) lymphoma in HIV-infected pediatric patients. A, two representative cases of LIP showing a polyclonal pattern (Cases 3 and 5, Tables 1 and 2); B, a representative case of pulmonary MALT lymphoma showing a dominant monoclonal band with a background polyclonal ladder (Case 6, Tables 1 and 2); $\mathbf{C}$, the patient with concurrent pulmonary MALT lymphoma and LIP; note that the LIP lesion showed a band slightly increased in intensity and of the same size as the monoclonal band amplified from the pulmonary MALT lymphoma lesion.

pared with normal lung tissues. IL-2, IL-4, IL-10, IL-6, and IL-10 have been shown to be essential for B-cell maturation, and therefore, T cells may determine not only the type of B-cell immune response but may also provide key molecules in B-cell lymphoma initiation and progression (30). IL-6 and IL-10 were variably expressed in LIP tissues and controls and may contribute to the activated B-cell population; however, viral genes such as EBV and HHV-8 did not play a role for B-cell stimulation and growth in these lesions. TNF- $\alpha$, GM-CSF, and IL-10 were variably expressed in LIP tissues and may explain the presence of activated macrophages in some of the LIP lesions. IL-4 mRNA was not detected in LIP lesions nor in control tissues. Therefore, we observed increased expression of certain cytokines and chemokines involved in lymphocyte activation and chemotaxis, possibly explaining the lymphoid cell infiltrates seen in pediatric LIP lesions. Similar to the case with the murine AIDS model, inappropriate interactions between Th1 T cells and antigen-presenting $\mathrm{B}$ cells may be inducing chronic IFN- $\gamma$ production, which causes chronic macrophage activation and ultimate sustained inflammation and tissue remodeling of the lung in pediatric LIP patients.

The presence of activated lymphoid cells may contribute to the evolution of a clonal B-cell pop-

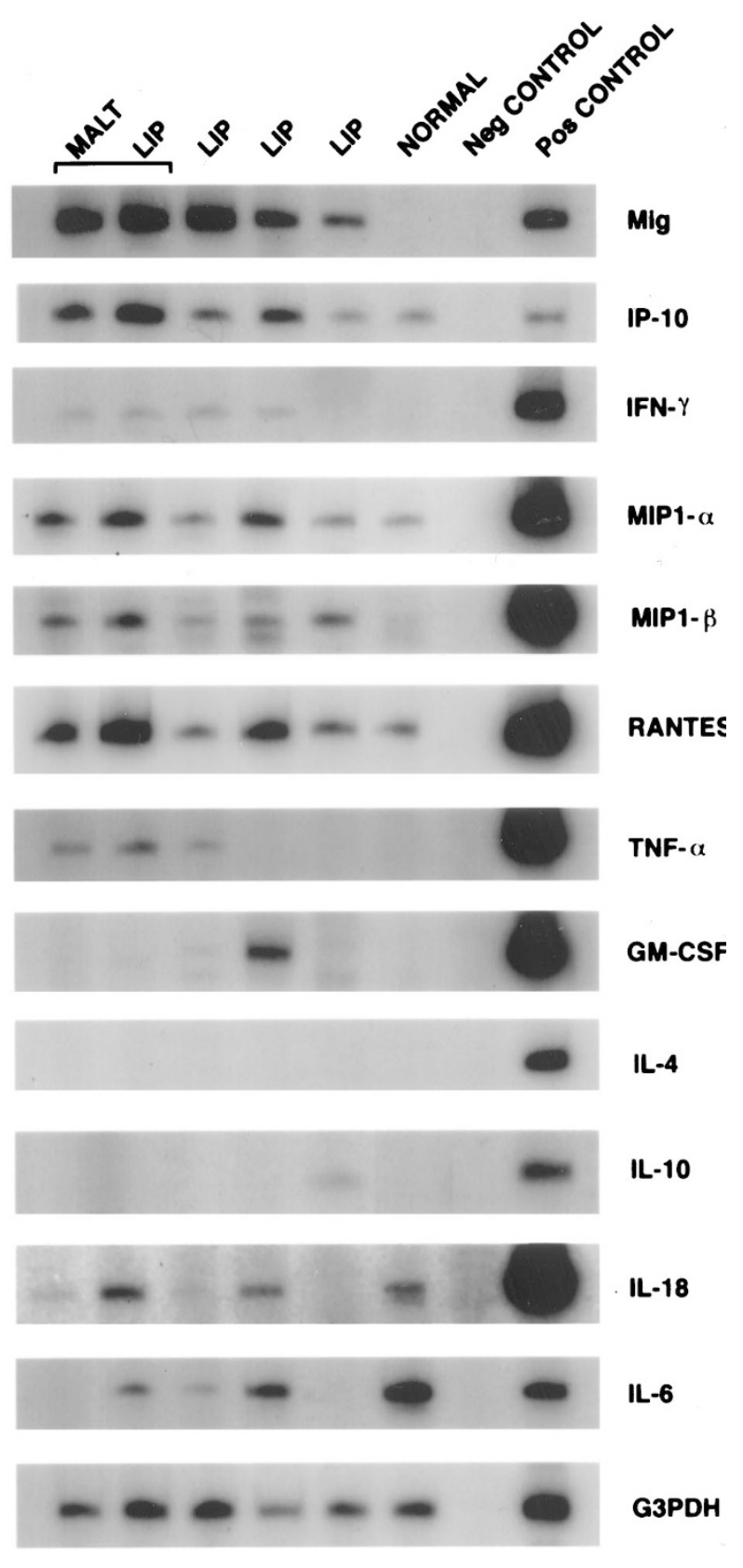

FIGURE 3. Patterns of cytokine and chemokine mRNA expression from paraffin-embedded tissues representative of lymphoid interstitial pneumonitis and pulmonary mucosa-associated lymphoid tissue lymphoma from HIV-positive pediatric patients, compared with a representative case of normal lung control tissue from a non-HIV infected patient. Total RNA was extracted and subjected to RT-PCR analysis using appropriately designed primers and conditions after normalization for G3PDH (Table 3).

ulation, indicating a clonal relationship between pulmonary LIP and MALT lymphoma in pediatric HIV-infected patients. By VDJ-PCR analysis, we demonstrated that clonal expansion may develop from a polyclonal or oligoclonal process. This was especially evident in the patient with concurrent LIP and pulmonary MALT lymphoma showing a monoclonal band of the same size in both the LIP and MALT lesion, and chemokine and cytokine mRNAs for Mig, IP-10, IFN- $\gamma$, RANTES, MIP1- $\alpha$ and $\beta$, 


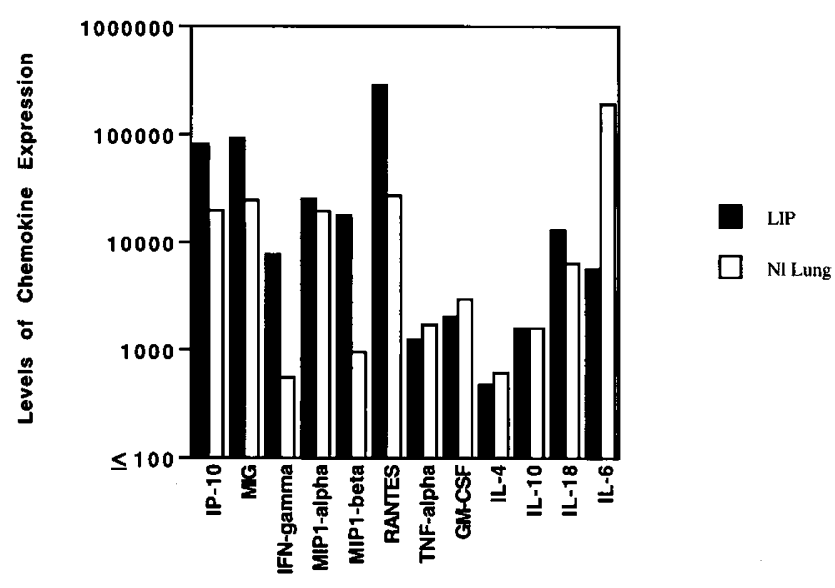

FIGURE 4. Levels of chemokine mRNA expression in five biopsies of lymphoid interstitial pneumonitis (LIP) and pulmonary mucosaassociated lymphoid tissue lymphoma from HIV-positive pediatric patients and five normal lung controls from non-HIV infected patients. Total cellular RNA, extracted from paraffin-embedded tissues diagnosed with LIP (solid square) and normal lung tissue (open square) was subjected to semiquantitative RT-PCR. After normalization to a standard RNA preparation and to G3PDH, the results of phosphorimage analysis are shown and plotted logarithmically as the geometric means of normalized arbitrary units (pixels)/group for each respective chemokine.

and TNF- $\alpha$ were present in both the LIP and MALT lesion in this patient, indicating that a microenvironment of activated $\mathrm{T}$ cells and macrophages may have contributed to the evolution of a monoclonal B-cell population to evolve.

Finally, we also showed that VDJ-PCR can be diagnostically useful in distinguishing MALT lymphoma from LIP. Surgical excision appears to be adequate treatment for isolated pulmonary MALT lymphoma in this setting. Of the six patients on whom clinical follow-up was available, Patients 1,2 , and 4 (Table 2) are well, off steroids, with no recurrence to date. Patient 6 developed a lymphoproliferative process in the parotid gland, was treated with interferon- $\alpha$ and retinoic acid, and is now well, off chemotherapy with no recurrence.

Acknowledgments: The authors thank Jared Berkowitz and Dr. Joyce Setsuda for laboratory assistance and support. The authors also thank Cindy Harris and Sarah E. Delay for assistance with immunohistochemical stains.

\section{REFERENCES}

1. DiCarlo FJ Jr, Joshi VV, Oleske JM, Connor EM. Neoplastic diseases in children with acquired immunodeficiency syndrome. Prog AIDS Pathol 1990;2:163-85.

2. Rubinstein A, Morecki R, Silverman B, Charytan M, Krieger BZ, Andiman W, et al. Pulmonary disease in children with acquired immune deficiency syndrome and AIDS-related complex. J Pediatr 1986;108:498-503.

3. Izraeli S, Mueller BU, Ling A, Temeck BK, Lewis LL, Chang R, et al. Role of tissue diagnosis in pulmonary involvement in pediatric human immunodeficiency virus infection. Pediatr Infect Dis J 1996;15:112-6.

4. Joshi VV, Gagnon GA, Chadwick EG, Berard CW, McClain KL, Leach CT, et al. The spectrum of mucosa-associated lymphoid tissue lesions in pediatric patients infected with HIV: a clinicopathologic study of six cases. Am J Clin Pathol 1997; 107:592-600.

5. Mishalani SH, Lones MA, Said JW. Multilocular thymic cyst. A novel thymic lesion associated with human immunodeficiency virus infection. Arch Pathol Lab Med 1995;119:46770 .

6. Leonidas JC, Berdon WE, Valderrama E, Neveling U, Schuval $\mathrm{S}$, Weiss SJ, et al. Human immunodeficiency virus infection and multilocular thymic cysts. Radiology 1996;198:377-9.

7. Thejpal R, Vaithilingum M, Chetty R, Coovadia HM. MALT lymphoma. Lancet 1997;349:434-5.

8. Kontny HU, Sleasman JW, Kingma DW, Jaffe ES, Avila NA, Pizzo PA, et al. Multilocular thymic cysts in children with human immunodeficiency virus infection: clinical and pathologic aspects. J Pediatr 1997;131:264-70.

9. Isaacson P, Wright DH. Extranodal malignant lymphoma arising from mucosa-associated lymphoid tissue. Cancer 1984;53:2515-24.

10. Jaffe ES, Harris NL, Stein H, Vardiman JW. Tumours of the haematopoietic and lymphoid tissues. Lyon, France: IARC Press; 2001.

11. Sundeen JT, Longo DL, Jaffe ES. CD5 expression in B-cell small lymphocytic malignancies. Correlations with clinical presentation and sites of disease. Am J Surg Pathol 1992;16: $130-7$.

12. Wotherspoon AC, Doglioni C, Isaacson PG. Low-grade gastric B-cell lymphoma of mucosa-associated lymphoid tissue (MALT): a multifocal disease. Histopathology 1992;20:29-34.

13. Isaacson PG. Pathogenesis and early lesions in extranodal lymphoma. Toxicol Lett 1993;67:237-47.

14. Teruya-Feldstein J, Temeck BK, Sloas MM, Kingma DW, Raffeld M, Pass HI, et al. Pulmonary malignant lymphoma of mucosa-associated lymphoid tissue (MALT) arising in a pediatric HIV-positive patient. Am J Surg Pathol 1995;19:35763.

15. Teruya-Feldstein J, Temeck BK, Sloas MM, Kingma DW, Raffeld M, Pass HI, et al. Pulmonary malignant lymphoma of mucosa-associated lymphoid tissue (MALT) arising in a pediatric HIV-positive patient. Am J Surg Pathol 1996;20:643-4.

16. Gould SJ, Isaacson PG. Bronchus-associated lymphoid tissue (BALT) in human fetal and infant lung. J Pathol 1993;169: 229-34.

17. Pahwa S, Kaplan M, Fikrig S, Pahwa R, Sarngadharan MG, Popovic M, et al. Spectrum of human T-cell lymphotropic virus type III infection in children. Recognition of symptomatic, asymptomatic, and seronegative patients. Jama 1986; 255:2299-305.

18. Falloon J, Eddy J, Wiener L, Pizzo PA. Human immunodeficiency virus infection in children. J Pediatr 1989;114:1-30.

19. Cohen D, Fitzpatrick E, Hartsfield C, Avdiushko M, Gillespie M. Abnormal lung cytokine synthesis by immunodeficient $\mathrm{T}$ cells in murine AIDS-associated interstitial pneumonitis. Ann N Y Acad Sci 1996;796:47-58.

20. Cohen DA, Fitzpatrick EA, Hartsfield C, Gillespie MN, Avdiushko M, Kaplan AM. Pulmonary lymphoid cell activation and cytokine expression in murine AIDS-associated interstitial pneumonitis. Am J Respir Cell Mol Biol 1997;16:153-61.

21. Segal GH, Jorgensen T, Masih AS, Braylan RC. Optimal primer selection for clonality assessment by polymerase chain reaction analysis: I. Low grade B-cell lymphoproliferative disorders of nonfollicular center cell type. Hum Pathol 1994;25:1269-75.

22. Otsuki T, Kumar S, Ensoli B, Kingma DW, Yano T, StetlerStevenson M, et al. Detection of HHV-8/KSHV DNA se- 
quences in AIDS-associated extranodal lymphoid malignancies. Leukemia 1996;10:1358-62.

23. Teruya-Feldstein J, Jaffe ES, Burd PR, Kanegane H, Kingma DW, Wilson WH, et al. The role of Mig, the monokine induced by interferon-gamma, and IP-10, the interferongamma-inducible protein-10, in tissue necrosis and vascular damage associated with Epstein-Barr virus-positive lymphoproliferative disease. Blood 1997;90:4099-105.

24. Isaacson PG, Spencer J. Gastric lymphoma and Helicobacter pylori. Important Adv Oncol 1996;43:111-21.

25. Hussell T, Isaacson PG, Crabtree JE, Spencer J. Helicobacter pylori-specific tumour-infiltrating $\mathrm{T}$ cells provide contact dependent help for the growth of malignant B cells in lowgrade gastric lymphoma of mucosa-associated lymphoid tissue. J Pathol 1996;178:122-7.

26. Liao F, Rabin RL, Yannelli JR, Koniaris LG, Vanguri P, Farber JM. Human Mig chemokine: biochemical and functional characterization. J Exp Med 1995;182:1301-14.
27. Taub DD, Lloyd AR, Conlon K, Wang JM, Ortaldo JR, Harada A, et al. Recombinant human interferon-inducible protein 10 is a chemoattractant for human monocytes and $\mathrm{T}$ lymphocytes and promotes T cell adhesion to endothelial cells. J Exp Med 1993;177:1809-14.

28. Okamura H, Tsutsi H, Komatsu T, Yutsudo M, Hakura A, Tanimoto $\mathrm{T}$, et al. Cloning of a new cytokine that induces IFN-gamma production by T cells. Nature 1995;378:88-91.

29. Ushio S, Namba M, Okura T, Hattori K, Nukada Y, Akita K, et al. Cloning of the cDNA for human IFN-gamma-inducing factor, expression in Escherichia coli, and studies on the biologic activities of the protein. J Immunol 1996;156: 4274-9.

30. Greiner A, Knorr C, Qin Y, Sebald W, Schimpl A, Banchereau J, et al. Low-grade B-cell lymphomas of mucosa-associated lymphoid tissue (MALT-type) require CD40-mediated signaling and Th2-type cytokines for in vitro growth and differentiation. Am J Pathol 1997;150:1583-93. 